\title{
Molecular Diversity of Ralstonia solanacearum Isolated from Ginger in Hawaii
}

\author{
Q. Yu, A. M. Alvarez, P. H. Moore, F. Zee, M. S. Kim, A. de Silva, P. R. Hepperly, and R. Ming
}

First and eighth authors: Hawaii Agriculture Research Center, Aiea 96701; first author: Department of Molecular Biosciences and Biosystems Engineering, University of Hawaii, Honolulu 96822; second and sixth authors: Department of Plant and Environmental Protection Sciences, University of Hawaii; fifth author: Department of Tropical Plant and Soil Sciences, University of Hawaii; and third, fourth, and seventh authors: U.S. Department of Agriculture-Agricultural Research Service, Pacific Basin Agricultural Research Center, Hilo, HI 96720.

Accepted for publication 27 March 2003.

\section{ABSTRACT}

Yu, Q., Alvarez, A. M., Moore, P. H., Zee, F., Kim, M. S., de Silva, A., Hepperly, P. R., and Ming, R. 2003. Molecular diversity of Ralstonia solanacearum isolated from ginger in Hawaii. Phytopathology 93:11241130 .

The genetic diversity of Ralstonia solanacearum strains isolated from ginger (Zingiber officinale) growing on the island of Hawaii was determined by analysis of amplified fragment length polymorphisms (AFLPs). Initially 28 strains of $R$. solanacearum collected from five host plant species worldwide were analyzed by AFLP. A second analysis was conducted on $55 R$. solanacearum strains collected from three ginger farms along the Hamakua Coast of Hawaii, the principle area of ginger cultivation in the state. From the initial analysis, $R$. solanacearum strains from ginger in Hawaii showed a high degree of similarity at 0.853 . In contrast, the average genetic similarity between $R$. solanacearum strains from heliconia and ginger was only 0.165 , and strains from ginger showed little similarity with strains from all other hosts. The second analysis of 55 strains from ginger on different Hawaiian farms confirmed that they were distinct from race 1 strains from tomato. Strains from ginger also showed greater diversity among themselves in the second analysis, and the greatest diversity occurred among strains from a farm where ginger is frequently imported and maintained. Our results provide evidence that $R$. solanacearum strains from ginger in Hawaii are genetically distinct from local strains from tomato (race 1) and heliconia (race 2).

Additional keyword: bacterial wilt, phylogeny.
Ralstonia solanacearum (Smith) Yabucchi causes bacterial wilt on several hundred plant species, including crops such as potato, tomato, tobacco, banana, peanut, and ginger, and it is responsible for substantial yield losses worldwide $(10,16)$. In Hawaii, bacterial wilt is a limiting factor in ginger production and is reported to have caused losses over 50\% during harvests in 1998 and 1999. In the absence of resistant cultivars, disease control is dependent on detecting the pathogen in soil and propagation materials and planting pathogen-free propagative materials into areas free of a soilborne pathogenic $R$. solanacearum population. This is difficult because $R$. solanacearum consists of a large and complex group of strains that are not universally detected by a single probe. Although specific probes are now available for detection and identification of different $R$. solanacearum populations $(12,28,30)$, their reactivities with local $R$. solanacearum strains that wilt ginger is unknown. An understanding of pathogen diversity in local farms is essential for utilization and further development of appropriate detection methods.

$R$. solanacearum has been divided into three races based on the host range of the pathogen $(3,4)$. Race 1 affects a wide range of hosts including potato, tomato, tobacco, diploid banana, peanut, ginger, and olive $(6,25,32)$. Race 2 is limited to musaceous hosts, such as heliconia and triploid banana. Race 3 affects potato, particularly under cool environments. Quinon et al. (29) were the first to show host specificity of certain isolates that would justify separation of the ginger strains into a separate race 4 . Strains from mulberry were also classified as race 4 by $\mathrm{He}$ et al. (20). In later

Corresponding author: R. Ming; E-mail address: rming@harc-hspa.com

Publication no. P-2003-0625-02R

(c) 2003 The American Phytopathological Society publications, the ginger strains were classified as race 4 and the mulberry strains as race $5(16,17)$.

Hayward (15) and subsequent workers divided $R$. solanacearum into four, and later five, biovars based on differences in their ability to produce acid from three disaccharides (maltose, lactose, and cellobiose) and oxidize three hexose alcohols (mannitol, sorbitol, and dulcitol) $(15,18,20)$. In 1992, Hayward et al. (19) also identified a tropical variant of biovar 2 (N2 or $2 \mathrm{~T})$, now referred to as the sixth biovar. Pegg and Moffett (25) showed that both biovars 3 and 4 of $R$. solanacearum can attack ginger, but in Australia, only strains belonging to biovar 4 were highly virulent and destructive. Highly aggressive biovar 3 strains from Kerala, India, that wilted ginger plants in 4 to 6 days as opposed to less aggressive strains that take 10 days to exhibit symptoms have recently been reported (S. K. Mathew, D. Girija, K. S. Binimol, and D. James, unpublished data; A. Kumar, personal communication).

Restriction fragment length polymorphism (RFLP) has been used to study the relationship of $R$. solanacearum strains representing the three races and five biovars (6). Nine probes were employed, seven of which encode proteins required for virulence and the hypersensitive response (6). It was hypothesized that virulence and hypersensitive markers might provide especially relevant information on pathogenic relationships. The results of this study provided a classification system separating $R$. solanacearum strains into two major divisions. Division I strains, including some strains from ginger, were mostly isolated from Asia, and division II strains were mostly from America (6-8). Division I contained all members of race 1 biovars 3, 4, and 5; and division II contained all members of race 1 biovar 1 and races 2 and 3. Twentyeight distinct RFLP groups, which were later designated multilocus genotypes (MLGs), were distinguished among sixty-two $R$. solanacearum strains representing all races and biovars (6). In a 
later study, the genetic analysis included 102 additional strains, and 46 MLGs were identified (8). Eleven (race 1 biovar 4) strains isolated from ginger in Australia and China were in MLG 23 (8). Classification of $R$. solanacearum into two divisions was further supported by evidence from $16 \mathrm{~S}$ rRNA sequence analysis (23, $26,31,34$ ), polymerase chain reaction (PCR)-RFLP of the $h r p$ gene region $(26,27)$, and amplified fragment length polymorphism (AFLP) (26).

The most recently proposed taxonomic scheme, which is based on genotypic rather than phenotypic characteristics, redefines the species complex in terms of subspecific "phylotypes," based on sequence analysis of the $16 \mathrm{~S}-23 \mathrm{~S}$ intergenic spacer region, infrasubspecific "sequevars," based on endoglucanase gene sequencing, and clonal lines, based on DNA fingerprinting analysis (11). The current taxonomy necessitates a reevaluation of genetic diversity of $R$. solanacearum strains from ginger.

An initial AFLP fingerprinting analysis of 10 strains from ginger clustered Hawaiian strains and clearly separated them from a Philippine strain and from $R$. solanacearum strains isolated from other hosts and locations (2). The objective of the present study was to determine the genetic diversity of strains of $R$. solanacearum collected from ginger on the island of Hawaii and to compare these local strains with $R$. solanacearum strains collected worldwide from a variety of hosts.

\section{MATERIALS AND METHODS}

Bacterial strains. Twenty-eight $R$. solanacearum strains (set I) were obtained from international collections representing five different host plant species and nine countries (Table 1). Among these were three blood disease bacteria (BDB) isolated from ba- nana in Indonesia. All strains were maintained as suspensions in sterile water and were retrieved by plating on PY medium $(8 \mathrm{~g}$ of peptone, $1 \mathrm{~g}$ of yeast extract, and $18 \mathrm{~g}$ of agar in 1 liter of distilled water supplemented with tetrazolium chloride [0.001\%] after autoclaving). All 28 strains were tested for reactions with genusspecific monoclonal antibodies (MAbs Ps1 and Ps1a) and enzyme-linked immunosorbent assay was used to confirm that they were $R$. solanacearum strains (1). Only those strains that were positive for both antibodies were included in the AFLP analyses.

The genetic diversity of 55 additional strains (set II) isolated from ginger in October 2001 from three farms on the island of Hawaii was analyzed. These strains were designated as B, DSK, and PO to represent the farms. Six strains, including two from ginger isolated in 1993, two from tomato in set I, and two additional strains from tomato (Table 1) were included. All strains used for the final AFLP analyses tested positive with MAbs Ps1 and Psla (1).

Culture conditions and DNA extraction. Bacterial stocks were grown on PY for $72 \mathrm{~h}$ at $29^{\circ} \mathrm{C}$. Single colonies were used to inoculate BG broth ( $10 \mathrm{~g}$ of peptone, $1 \mathrm{~g}$ of glucose, $1 \mathrm{~g}$ of casamino acids, and $1 \mathrm{~g}$ of yeast extract per liter). The $R$. solanacearum strains were grown in $5 \mathrm{ml}$ of BG broth for 18 to $24 \mathrm{~h}$. Genomic DNA was extracted based on the procedure described by Chen and Kuo (5). DNA samples were purified and quantified before restriction digestion.

AFLP analysis. A preliminary screen for polymorphisms was carried out on four $R$. solanacearum strains, two BDB strains, one Enterobacter cloacae strain, and a distantly related Sphingomonas paucimobilis strain. The protocol outlined by Vos et al. (35) was used for digestion of genomic DNA with the following adjustment in the digestion conditions: $250 \mathrm{ng}$ of DNA was digested with

TABLE 1. Characteristics of Ralstonia solanacearum strains used in this study

\begin{tabular}{|c|c|c|c|c|c|c|c|c|}
\hline Strain no. & Alternate strain no(s). & Host & Origin & Race & Biovar & Ecotype & MLG & Provider \\
\hline A4606 & BD-1 & Banana & Indonesia & $\ldots$ & $\ldots$ & $\mathrm{BD}^{\mathrm{a}}$ & $\ldots$ & Buddenhagen \\
\hline A4610 & BD-4 & Banana & Indonesia & $\ldots$ & $\ldots$ & $\mathrm{BD}$ & $\ldots$ & Buddenhagen \\
\hline A4612 & BD-6 & Banana & Indonesia & $\ldots$ & $\ldots$ & $\mathrm{BD}$ & $\ldots$ & Buddenhagen \\
\hline A3381 & UW167, K160 & Banana & Costa Rica & 2 & 1 & $\mathrm{~B}$ & 24 & Sequeira \\
\hline A4125 & BIOTE 1694 & Banana & Philippines & 2 & 1 & Bugtok $^{b}$ & $\ldots$ & Natural \\
\hline A4128 & BIOTE 1690 & Banana & Philippines & 2 & 1 & Bugtok & $\ldots$ & Natural \\
\hline A4493 & UW10, K204, S164 & Heliconia & Costa Rica & 2 & 1 & $\ldots$ & $\ldots$ & Sequeira \\
\hline A3447 & UW19, S205 & Potato & Colombia & 3 & 2 & $\ldots$ & 27 & Thurston \\
\hline A4496 & UW35, K228 & Heliconia? Banana & Colombia & 2 & 1 & $\mathrm{~B}$ & $\ldots$ & Buddenhagen \\
\hline A4497 & UW170, K229, B-H248 & Heliconia & Colombia & 2 & 1 & $\mathrm{D}$ & $\ldots$ & Buddenhagen \\
\hline A4494 & UW15, S200 & Banana & Honduras & 2 & 1 & SFR & $\ldots$ & Sequeira \\
\hline A4495 & UW20, K260, S215 & Banana & Venezuela & 2 & 1 & SFR & $28^{\mathrm{c}}$ & Buddenhagen \\
\hline A3911 & C1017-1A & Heliconia & Hawaii & 2 & 1 & $\ldots$ & $" 28 " \mathrm{c}$ & Ferreira \\
\hline A3916 & PS8 & Heliconia & Hawaii & 2 & 1 & $\ldots$ & $\ldots$ & Ferreira \\
\hline A3913 & KV5.1 & Heliconia & Hawaii & 2 & 1 & $\ldots$ & $\ldots$ & Ferreira \\
\hline A3915 & PS7 & Heliconia & Hawaii & 2 & 1 & $\ldots$ & $\ldots$ & Ferreira \\
\hline A3908 & KV2.2 & Heliconia & Hawaii & 2 & 1 & $\ldots$ & $\ldots$ & Ferreira \\
\hline A3906 & KV1.1 & Heliconia & Hawaii & 2 & 1 & $\ldots$ & $\ldots$ & Ferreira \\
\hline A3450 & UW30, K136 & Tomato & Trinidad & 1 & 1 & $\mathrm{~T}$ & 1 & Dudman \\
\hline A4492 & UW6, K119, S118 & Heliconia & Costa Rica & 2 & 1 & $\mathrm{R}$ & $\ldots$ & Sequeira \\
\hline A3459 & UW130, S225 & Tomato & Peru & 1 & 3 & $\mathrm{~T}$ & 9 & Sequeira \\
\hline A4515 & GW1 & Ginger & Hawaii & 4 & 4 & $\ldots$ & $\ldots$ & Trujillo \\
\hline A4516 & GW2 & Ginger & Hawaii & 4 & 4 & $\ldots$ & $\ldots$ & Trujillo \\
\hline A5181 & DP-6 & Ginger & Hawaii & 4 & 4 & $\ldots$ & $\ldots$ & Hepperley \\
\hline A5182 & DP-9 & Ginger & Hawaii & 4 & 4 & $\ldots$ & $\ldots$ & Hepperley \\
\hline A5183 & DP-11 & Ginger & Hawaii & 4 & 4 & $\ldots$ & $\ldots$ & Hepperley \\
\hline A5184 & DP-13 & Ginger & Hawaii & 4 & 4 & $\ldots$ & $\ldots$ & Hepperley \\
\hline A5185 & DP-22 & Ginger & Hawaii & 4 & 4 & $\ldots$ & $\ldots$ & Hepperley \\
\hline A3776 & T6 & Tomato & Philippines & 1 & 3 & $\ldots$ & $\ldots$ & Natural \\
\hline A5155 & UW25, K60 & Tomato & North Carolina & 1 & 1 & $\mathrm{~T}$ & 1 & Kelman \\
\hline
\end{tabular}

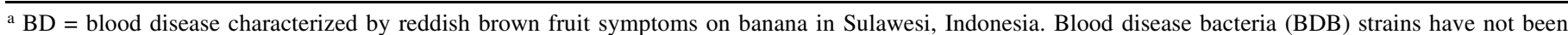
assigned to a multilocus genotype (MLG), but they show a totally different hybridization pattern compared with the other $R$. solanacearum strains tested (7).

${ }^{\mathrm{b}}$ Bugtok refers to the hardening and blacking of cooking banana fruits in the Philippines.

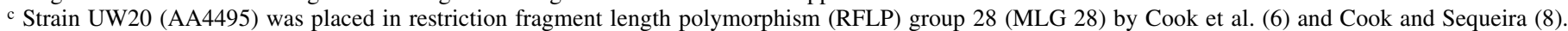
Sequence data from the endoglucanase gene confirmed the RFLP data, and heliconia strain A3911 was in MLG 28 . Because groups formed by endoglucanase data are not based on the probes used by Cook and Sequeira (8), the heliconia strain is classified as MLG "28" (P. Prior and M. Fegan, personal communication). 
5 units of EcoRI and 5 units of $M s e I$ at $37^{\circ} \mathrm{C}$ for $3 \mathrm{~h}$. The reaction conditions for adapter ligation and preamplification, described by Vos et al. (35), were followed with the exception that 1 unit of Taq polymerase was used.

Primer labeling and selective amplification. IRDye 700- and Dye 800-labeled EcoRI primers listed in Table 2 were purchased from Li-Cor (Lincoln, NE). MseI primers were obtained from Operon Technologies (Alameda, CA). The reaction conditions were determined according to the manufacturer's directions (Li-Cor).

Gel analysis. An equal volume of loading dye (95\% formamide, $20 \mathrm{mM}$ EDTA, and $0.08 \%$ bromophenol blue) was added to each sample, which was then denatured at $95^{\circ} \mathrm{C}$ for $3 \mathrm{~min}$ and placed on ice for $2 \mathrm{~min}$ before loading. The sample volume was set to $1.0 \mu \mathrm{l}$ and loaded with a Hamilton multichannel pipette (Hamilton Company, Reno, NV) onto $25-\mathrm{cm}$ gels prepared with $6.5 \% \mathrm{~KB}$ plus polyacrylamide gel matrix. Electrophoresis and detection of the AFLP fragments were performed on an automated DNA sequencer $\left(\mathrm{Li}-\mathrm{Cor} \mathrm{IR}^{2}\right)$. The electrophoresis parameters were set to $1,500 \mathrm{~V}, 40.0 \mathrm{~mA}, 40.0 \mathrm{~W}, 50^{\circ} \mathrm{C}$, and scan speed of 4 . The run time was set to $2.0 \mathrm{~h}$, and gel images were saved as .tif files for analysis.

Data analysis. The gel images were scored using a binary scoring system, recording the presence and absence of bands as 1 and 0 , respectively. Semiautomated scoring was performed initially with AFLP-Quantar (version 1.0, KeyGene Product, Wageningen, the Netherlands) and then manually to make adjustments to the automated score sheet when necessary. The data were exported into a spreadsheet and formatted for the NTSYSpc cluster analysis software (version 2.1, Exeter Software, Setaukat, NY). The AFLP marker data were used to compute pair-wise Dice coefficients (9). Cluster analysis was performed on the similarity matrix using the unweighted pair group method using arithmetic means algorithm (32) provided in the NTSYSpc software package. The cophenetic correlation coefficient was calculated to test the goodness of fit between the similarity and the cophenetic matrices.

\section{RESULTS}

The preliminary screen for polymorphisms carried out on the $R$. solanacearum, E. cloacae, and Sphingomonas strains identified primer sets used for the first analysis of $28 R$. solanacearum strains. Among the 28 sets of EcoRI/MseI primers with one to three nucleotide extensions surveyed, the number of polymorphic markers generated by each primer set ranged from 3 to 104 . The 12 primer sets showing the most polymorphisms were selected for genotyping $28 R$. solanacearum strains collected worldwide

TABLE 2. List of amplified fragment length polymorphism primers used in DNA fingerprinting of 28 Ralstonia solanacearum strains (set I) collected worldwide and 55 strains (set II) collected from ginger fields of three farms on the island of Hawaii

\begin{tabular}{|c|c|c|c|}
\hline & & \multicolumn{2}{|c|}{ Polymorphic markers } \\
\hline \multicolumn{2}{|c|}{ Primer combination $^{a}$} & Set I & Set II \\
\hline E-AGG & $\mathrm{M}-\mathrm{CG}$ & 49 & 89 \\
\hline E-ATC & $\mathrm{M}-\mathrm{CG}$ & 44 & 11 \\
\hline E-ACG & $\mathrm{M}-\mathrm{CG}$ & 50 & 30 \\
\hline E-AAC & $\mathrm{M}-\mathrm{CG}$ & 34 & 59 \\
\hline E-ACA & $\mathrm{M}-\mathrm{CA}$ & 59 & 83 \\
\hline E-AGC & M-CG & 38 & $\ldots$ \\
\hline E-ATT & $\mathrm{M}-\mathrm{CA}$ & 34 & 29 \\
\hline E-AGG & $\mathrm{M}-\mathrm{CA}$ & 46 & 46 \\
\hline E-AGA & M-CA & 39 & $\ldots$ \\
\hline E-ACG & $\mathrm{M}-\mathrm{CC}$ & 36 & 38 \\
\hline $\mathrm{E}-\mathrm{ACC}$ & M-CT & 74 & 36 \\
\hline E-ACC & $\mathrm{M}-\mathrm{CG}$ & $\ldots$ & 57 \\
\hline E-ATC & M-CT & 62 & $\ldots$ \\
\hline Total & & 565 & 478 \\
\hline
\end{tabular}

${ }^{a}$ E indicates EcoRI; M indicates MseI.
(Table 2). Each primer set generated 34 to 74 markers. A total of 565 polymorphic markers were detected and analyzed.

Because the set II samples were mostly $R$. solanacearum strains from ginger, a second preliminary screen was carried out on three strains (PO1, PO6, and PO11) from ginger in Hawaii. Among the 32 sets of EcoRI/MseI primers with three nucleotide extensions surveyed, the number of polymorphic markers generated by each primer set ranged from 4 to 65 . The 10 primer sets showing the greatest number of polymorphisms were selected for genotyping 55 R. solanacearum strains collected on the island of Hawaii (Table 1; Fig. 1). Each primer set generated 11 to 89 markers. A total of 478 polymorphic markers were detected and analyzed.

Molecular variability of $\boldsymbol{R}$. solanacearum strains from different regions of the world (set $I$ strains). The genetic variation among $28 R$. solanacearum strains was estimated using pair-wise comparison of genetic similarity. The average pair-wise genetic similarity was 0.307 and ranged from 0.075 to 0.951 . The most closely related strains, strains A3911 and A3916 from Hawaiian heliconia, shared most of their AFLP markers and had a genetic similarity of 0.951 . Two strains from ginger (A4515 and A4516) also clustered together at 0.944 . The most distantly related strains, strain A4492 from heliconia in Costa Rica and strain A3450 from tomato in Trinidad, had very few DNA markers in common with a genetic similarity of only 0.075 . Strains from ginger showed an average genetic similarity of 0.827 within the cluster but had very few DNA markers in common with strains from other hosts (similarity less than 0.140), except for one strain from heliconia in Costa Rica (A4492) and one strain from tomato in Peru (A3459), which showed a genetic similarity of 0.491 .

Pair-wise comparisons of genetic similarity of $R$. solanacearum strains within and among different host plants revealed narrow genetic diversity among strains from the same host within a confined geographic area. The average genetic similarity of strains from Hawaiian ginger and heliconia was 0.853 and 0.873 , respectively. In contrast, the average genetic similarity of heliconia strains from different countries was only 0.496 .

The relationships between $R$. solanacearum strains from ginger and strains from other hosts collected from different geographic areas were determined by cluster analysis on the 28 strains that were positive for MAbs Ps1 and Ps1a. The resulting dendrogram had five major clusters with similarity coefficients above 0.64 (Fig. 2). The first cluster included only BDB strains isolated from banana fruits showing blood disease in Indonesia. The second cluster contained race 2 biovar 1 strains isolated from banana and heliconia in Costa Rica and the Philippines. The third cluster included race 2 biovar 1 strains from banana and heliconia in Columbia. The fourth cluster included two strains from banana in Honduras and Venezuela and six race 2 biovar 1 strains from heliconia in Hawaii. The fifth cluster included seven strains from ginger in Hawaii. The remaining strains, A3447 from potato (Columbia), A3450 from tomato (Trinidad), A4492 from heliconia (Costa Rica), and A3459 from tomato (Peru), were not closely related to any of the above clusters.

Molecular variability of strains from Hawaiian ginger (set II strains). Results from set I showed high levels of genetic similarity among strains from ginger in Hawaii, confirming the results of an earlier study (2). A more comprehensive investigation carried out on 55 ginger strains collected from three farms on the island of Hawaii revealed greater diversity among local strains. The average genetic similarity among strains within each farm was $0.530,0.526$, and 0.463 for PO, B, and DSK, respectively. The average genetic similarity of all 55 strains from ginger in set II was 0.507 , whereas the average genetic similarity of strains from ginger in set I was 0.853 .

Cluster analysis separated ginger strains clearly from the four reference strains from tomato (reference strains A3776, A5155, A3459, and A3450 at the bottom of Figure 3). Although four subclusters can be recognized among the 55 ginger strains from three 
farms, no cluster was confined to a particular farm. Each subcluster included strains from all three farms (except subcluster III, which contained no DSK strains).

\section{DISCUSSION}

AFLP analysis of Ralstonia strains from set I samples provided evidence supporting the separation of strains from ginger from race 1 and 2 strains of $R$. solanacearum based on molecular marker dissimilarity. Strains from Hawaiian ginger (Fig. 2, cluster V) shared very little genetic similarity with strains from banana and heliconia. The BDB strains from banana in cluster I (Fig. 2) have been included in the $R$. solanacearum species complex but are clearly distinct from the $R$. solanacearum race 2 strains from banana (13). The close relationships between $R$. solanacearum race 2 biovar 1 strains from banana in the Philippines and race 2 biovar 1 strains from banana and heliconia in Costa Rica (Fig. 2, cluster II) support the hypothesis that these strains originated in the New World. Likewise, the geographic origin of cluster IV strains suggests that strains from heliconia may have been introduced to Hawaii on propagative stocks collected in Central and/or South America. The banana strain from Venezuela was in RFLP group 28 (6). Strains from Hawaiian heliconia were placed in MLG group 28 based on endoglucanase analysis (P. Prior and M. Fegan, personal communication). Although these analyses were not based on identical probes, there appears to be a close relationship among these groups. Division II biovar 1 strains from banana and heliconia are believed to be of New World origins, whereas division I biovar 4 strains from ginger are believed to have originated in Asia. These results support this view.

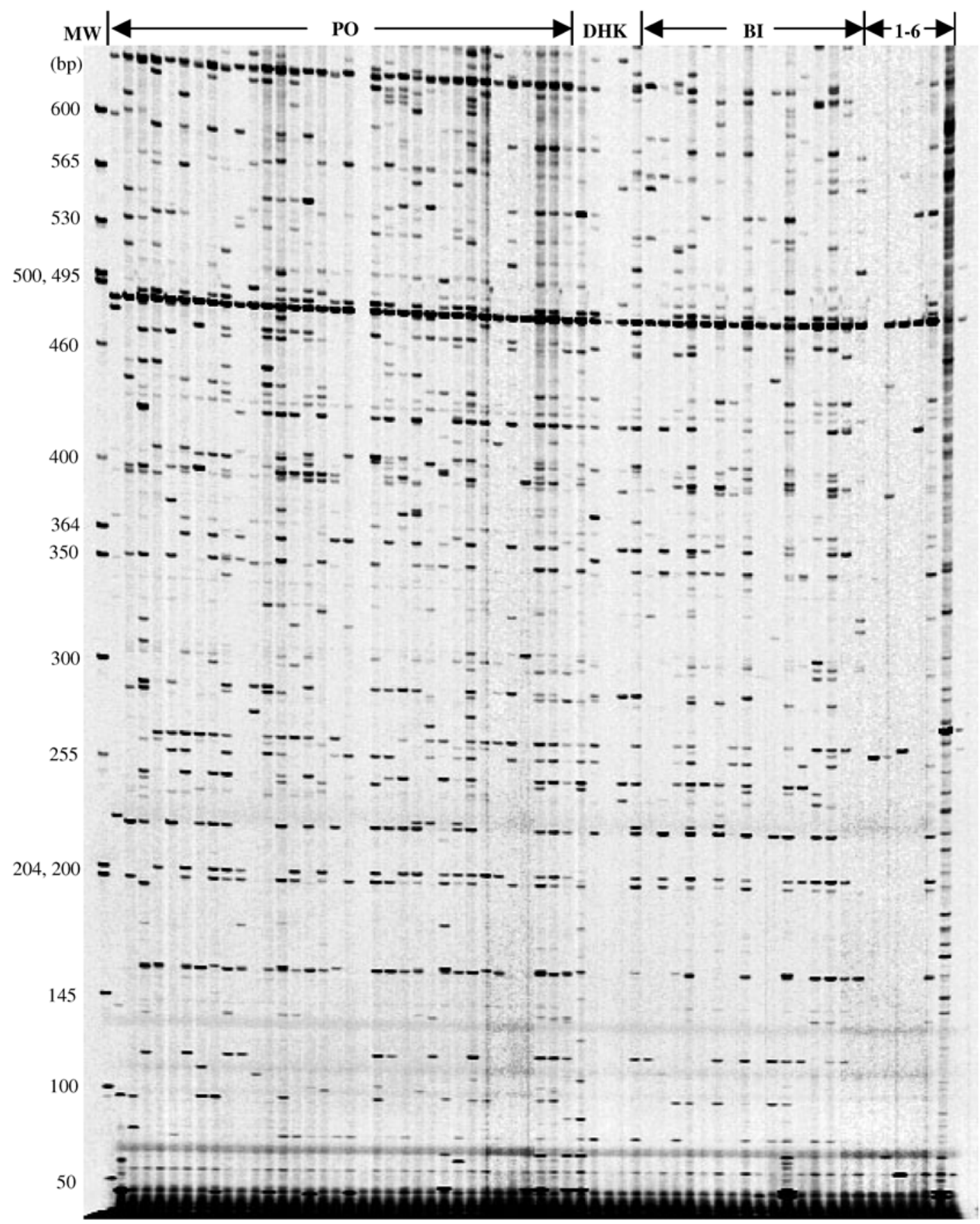

Fig. 1. Amplified fragment length polymorphism gel image of the Ralstonia solanacearum strains generated by an automatic DNA sequencer with the primer pair E-AGG/M-CG. Lane 1, molecular weight marker (MW). Lanes 2 to 35, strains from the farm PO. Lanes 36 to 40, strains from the farm DSK. Lanes 41 to 56, strains from the farm B. Lanes 57 to 62, reference strains (one to six) in the order of A3450, A3459, A3776, A4515, A4516, and A5155. 
The clustering of strains collected from the major ginger production area on the island of Hawaii suggests that they might have evolved from a small population. These results support the conclusion drawn from a previous RFLP analysis of a collection of strains that also showed a tight clustering of strains from Hawaiian ginger with a high level of genetic similarity and a clear separation from local strains from tomato and heliconia (1; A. M. Alvarez and J. Berestecky, unpublished data). Strains from $\mathrm{Ha}-$ waiian ginger also were clearly separated from a ginger strain from the Philippines (2).

Our larger scale investigation of 55 Hawaiian ginger strains revealed greater genetic diversity among the strains than evidenced in the first analysis, but no farm-specific subpopulation existed among strains from ginger in Hawaii. Ginger plants on the DSK farm consisted of a collection of clones of horticultural interest, and the five ginger strains collected from this farm were distributed widely among the clusters. The other farms were single clone plantings of either cv. Chinese White or Japanese Yellow, and strains from these farms also were evenly distributed. The selection of the six reference strains, based on our previous studies, included representative strains of tomato from different geographic regions and two strains from ginger, A4515 and A4516, isolated 8 years earlier in Hawaii (2). The strains from ginger clustered with the 55 new ginger strains from three additional farms, whereas the four strains from tomato differed considerably from the ginger strains (Fig. 3). When strains A4515 and A4516 were analyzed with only five other ginger strains from the set I samples, they were closely related (Fig. 2). When these two strains were reanalyzed with the 55 strains from ginger of the set II samples, greater diversity was detected, possibly due to partial degradation of the DNA from strain A4515 because it showed far fewer bands than A4516 in the set II analysis, whereas the banding patterns of these two strains were almost identical in the set I analysis. The DNA samples of the reference strains were prepared for the set I analysis and were thawed several times during the 5 months in a $-20^{\circ} \mathrm{C}$ freezer. The genomic DNA of 55 strains from three farms was freshly isolated when the AFLP analyses were performed. In the future, freshly isolated DNA samples should be used for all reference strains when conducting this type of experiment.

We have observed that some primer pairs generated more markers for certain groups of strains and fewer for others. Among the nine pairs of primers used on both set I and set II analyses, four pairs (E-AGG/M-CG, E-AAC/M-CG, E-AAC/M-CA, and EACG/M-CC) produced more markers in set II than in set I (Table 1). These data reflect higher frequency of restriction sites for these specific primer sequences within a group of strains. For example, the primer pair E-AGG/M-CG generated far more polymorphic markers on strains from ginger than on strains from tomato (Fig. 1). Our data added further support to the high resolution of AFLP markers for studying genetic diversity (26).

The AFLP technique has been vigorously tested for its reproducibility, and average error rates of 1 to $3 \%$ resulting from AFLP protocol, gel resolution, and human errors have been reported (14, 32). Based on our own experience, even the use of different PCR machines and automatic sequencers under identical conditions can produce fluctuations in the AFLP bands that are amplified and detected. For this reason, AFLP data from two different gels were difficult to compare when lacking a sufficient number of monomorphic bands as references. We were able to combine a larger
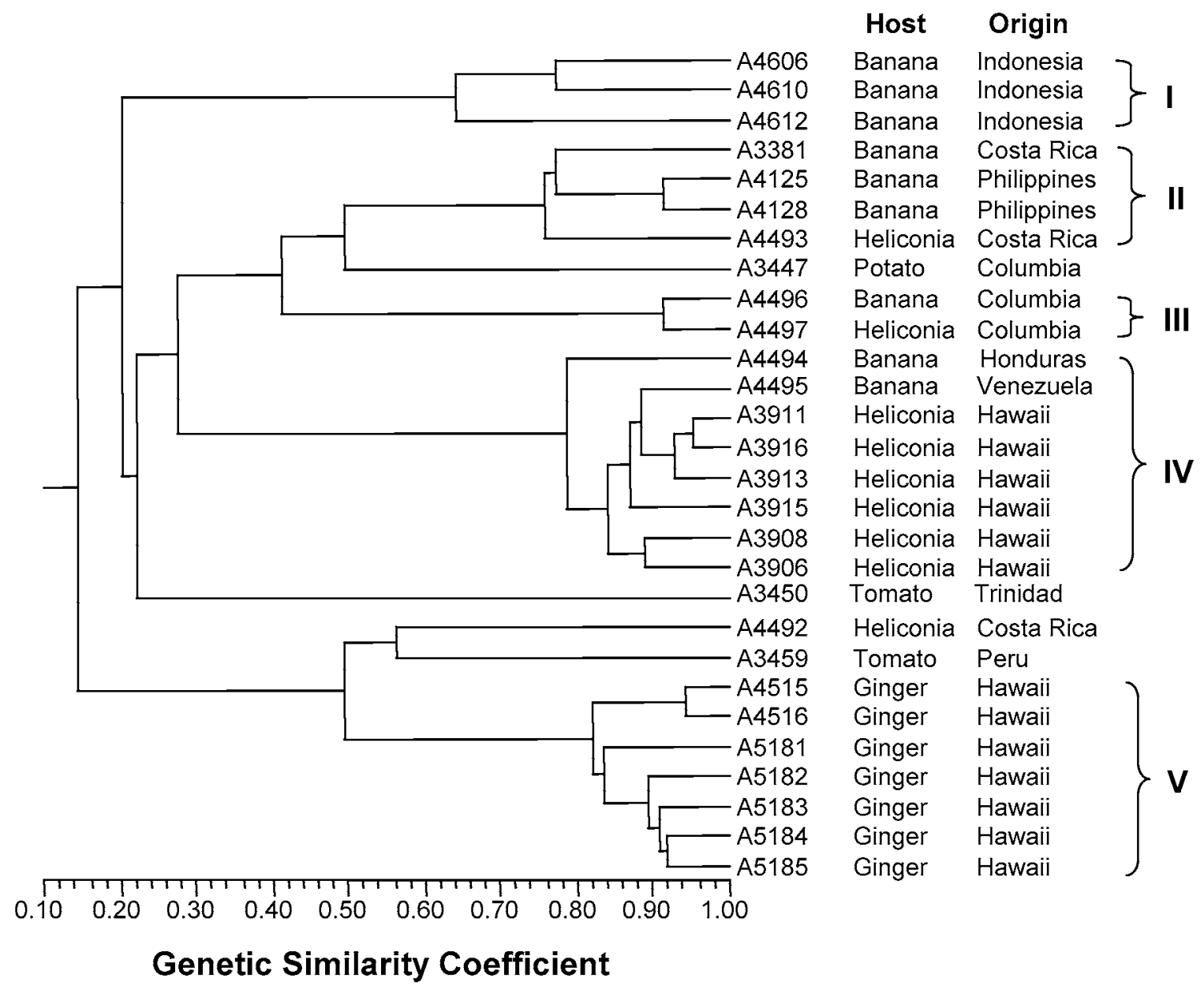

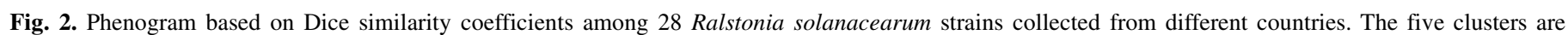
indicated by Roman numerals. The cophenetic correlation coefficient $=0.99$. 
number of samples from two different AFLP gels when we studied the genetic diversity of a self-pollinated plant species, Caraca papaya L., which shared a large portion of the AFLP markers in all samples (21). However, there were hardly any common markers among $R$. solanacearum strains, making it impossible to combine set I and set II AFLP data. We had the same problem with the large germ plasm collection of the self-incompatible plant species Ananas comosus L. (pineapple), which showed a tremendous amount of AFLP marker variation within the species. Thus, the entire collection had to be run in two sequencing gels, necessitating two separate cluster analyses with two sets of data (C. Y.
Kato, C. Nagai, P. H. Moore, F. Zee, M. S. Kim, D. L. Steiger, and R. Ming, unpublished data).

Considering the genome size of bacteria, we expected lower rates of polymorphism among bacterial strains than found within a species of higher plants. The initial primer survey included EcoRI and MseI primers with one, two, and three nucleotide extensions, whereas in plants, three nucleotide extensions are most frequently used $(21,33)$. The total number of DNA fragments amplified by primer pairs with three nucleotide extensions was very limited, reflecting the small genome of bacteria. However, the rate of polymorphism among strains was high, and there were, in fact, very

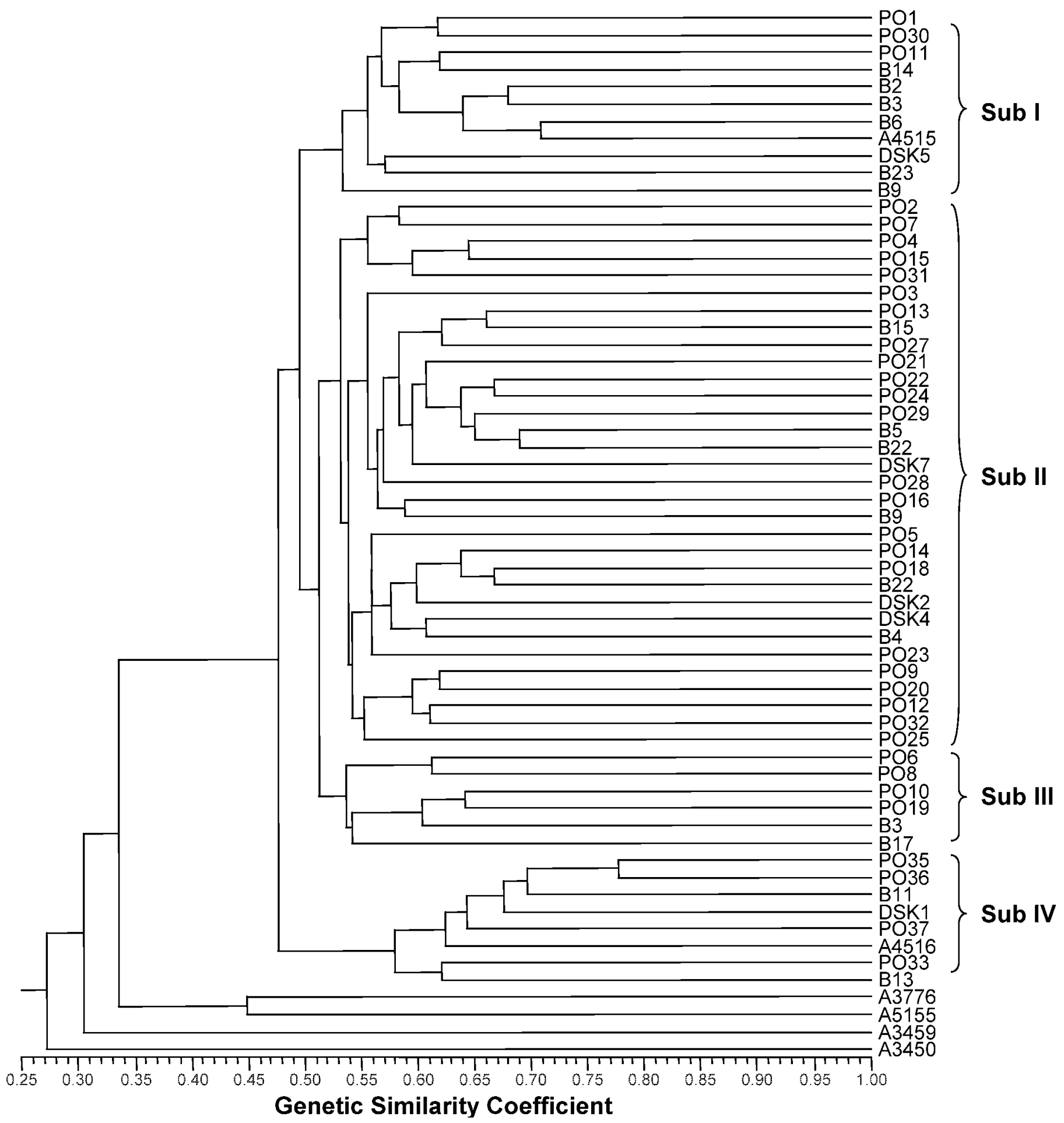

Fig. 3. Phenogram based on Dice similarity coefficients among 55 Ralstonia solanacearum strains collected from three ginger farms (B, DSK, and PO) on the island of Hawaii along with six reference strains. The hosts and origins of the six reference strains are A4515 and A4516 (ginger, Hawaii); A3776 (tomato, Philippines); A5155 (tomato, North Carolina); A3459 (tomato, Peru); and A3450 (tomato, Trinidad). The cophenetic correlation coefficient $=0.83$. 
few monomorphic bands. This high polymorphism rate is likely the consequence of a rapid evolutionary process as a result of the short generation time in bacteria compared with that of higher plants and animals.

We initially included bacterial strains from different genera as out-groups, but the resolution of the AFLP analysis was too high for inclusion of other genera. In higher plants, the application of AFLP markers for taxonomic classification above the species level has been recognized as limited (22), and the same restriction has been suggested for bacteria as well (24). We concur with the proposal that AFLP analysis is best used to complement other molecular fingerprinting techniques for analysis of closely related populations, whereas other methods of analysis should be used to differentiate populations of $R$. solanacearum at higher taxonomic levels (11).

\section{ACKNOWLEDGMENTS}

This work was supported by the U.S. Department of Agriculture-Agricultural Research Service Cooperative Agreements (grants 58-5320-3460, 58-5320-1-368, and 58-5320-9-105) with the Hawaii Agriculture Research Center. We thank M. Shintaku, D. Sato, K. Nishijima, H. Johnson, D. Pinner, and R. Shoemaker for help with sample collection; and R. Osgood, M.-L. Wang, and S. Whalen for reviewing the manuscript.

\section{LITERATURE CITED}

1. Alvarez, A. M., Berestecky, J., Stiles, J. I., Ferreira, S. A., and Benedict, A. A. 1993. Serological and molecular approaches to identification of Pseudomonas solanacearum strains from heliconia. Pages 62-69 in: Bacterial Wilt. Proc. Int. Conf. G. L. Hartman and A. C. Hayward, eds. ACIAR Proc. No. 45.

2. Alvarez, A. M., Trotter, K. J., Swafford, M. B., Berestecky, J. M., Yu, Q., Ming, R., Hepperly, P. R., and Zee, F. Characterization and detection of Ralstonia solanacearum strains causing bacterial wilt of ginger in Hawaii. Proc. Int. Bact. Wilt Symp., 3rd. C. Allen, P. Prior, and A. C. Hayward, eds. The American Phytopathological Society, St. Paul, MN. (In press.)

3. Buddenhagen, I. W., and Kelman, A. 1964. Biological and physiological aspects of bacterial wilt caused by Pseudomonas solanacearum. Annu. Rev. Phytopathol. 2:203-230.

4. Buddenhagen, I. W., Sequeira, L., and Kelman, A. 1962. Designation of races in Pseudomonas solanacearum. Phytopathology 52:726.

5. Chen, W.-P., and Kuo, T.-T. 1993. A simple and rapid method for the preparation of gram-negative bacterial genomic DNA. Nucleic Acids Res. 21:2260-2261.

6. Cook, D., Barlow, E., and Sequeira, L. 1989. Genetic diversity of Pseudomonas solanacearum: Detection of restriction fragment length polymorphism with DNA probes that specify virulence and the hypersensitive response. Mol. Plant-Microbe Interact. 2:113-121.

7. Cook, D., Barlow, E., and Sequeira, L. 1991. DNA probes as tools for the study of host-pathogen evolution: The example of Pseudomonas solanacearum. Pages 103-108 in: Advances in Molecular Genetics of Plant-Microbe Interactions. Vol. 1. H. Henneke and D. P. S. Verma, eds. Kluwer Academic Publishers, Dordrecht, the Netherlands.

8. Cook, D., and Sequeira, L. 1994. Strain characterization of Pseudomonas solanacearum by molecular genetic methods. Pages 77-93 in: Bacterial Wilt: The Disease and Its Causative Agent, Pseudomonas solanacearum. A. C. Hayward and G. L. Hartman, eds. CAB International, Wallingford, UK.

9. Dice, L. R. 1945. Measures of the amount of ecological association between species. Ecology 26:297-302.

10. Elphinstone, J. Distribution and economic losses due to Ralstonia solanacearum. Proc. Int. Bact. Wilt Symp., 3rd. C. Allen, P. Prior, and A. C. Hayward, eds. The American Phytopathological Society, St. Paul, MN. (In press.)

11. Fegan, M., and Prior, P. How complex is the Ralstonia solanacearum species complex? Proc. Int. Bact. Wilt Symp., 3rd. C. Allen, P. Prior, and A. C. Hayward, eds. The American Phytopathological Society, St. Paul, MN. (In press.)

12. Fegan, M., Taghavi, M., Sly, L. I., and Hayward, A. C. 1998. Phylogeny, diversity and molecular diagnostics of Ralstonia solanacearum. Pages 19-33 in: Bacterial Wilt Disease: Molecular and Ecological Aspects. P. Prior, C. Allen, and J. Elphinstone, eds. INRA Editions, Springer-Verlag, Berlin.
13. Gillings, M. R., and Fahy, P. 1994. Genomic fingerprinting: Towards a unified view of the Pseudomonas solanacearum species complex. Pages 95-112 in: Bacterial Wilt: The Disease and Its Causative Agent, Pseudomonas solanacearum. A. C. Hayward and G. L. Hartman, eds. CAB International, Wallingford, UK.

14. Hansen, M., Kraft, T., Christiansson, M., and Nilsson, N.-O. 1999 Evaluation of AFLP in Beta. Theor. Appl. Genet. 98:845-852.

15. Hayward, A. C. 1964. Characteristics of Pseudomonas solanacearum. J. Appl. Bacteriol. 27:265-277.

16. Hayward, A. C. 1991. Biological and epidemiology of bacterial wilt caused by Pseudomonas solanacearum. Annu. Rev. Phytopathol. 29:6587.

17. Hayward, A. C. 1994. Systematics and phylogeny of Pseudomonas solanacearum and related bacteria. Pages 123-135 in: Bacterial Wilt: The Disease and Its Causative Agent, Pseudomonas solanacearum. A. C. Hayward and G. L. Hartman, eds. CAB International, Wallingford, UK.

18. Hayward, A. C., El-Nashaar, H. M., Nydegger, U., and De Lindo, L. 1990. Variation in nitrate metabolism in biovars of Pseudomonas solanacearum. J. Appl. Bacteriol. 69:269-280.

19. Hayward, A. C., Sequeira, L., French, E. R., El-Nashar, H. M., and Nydegger, U. 1992. Tropical variant of biovar 2 of Pseudomonas solanacearum. (Abstr.) Phytopathology 82:608.

20. He, L., Sequeira, L., and Kelman, A. 1983. Characteristics of strains of Pseudomonas solanacearum from China. Plant Dis. 67:1357-1361.

21. Kim, M. S., Moore, P. H., Zee, F., Fitch, M. M., Steiger, D. L., Manshardt, R. M., Paull, R. E., Drew, R., Sekioka, A. T., and Ming, R. 2002. Genetic diversity of Carica papaya L. as revealed by AFLP markers. Genome 45:503-512.

22. Lerceteau, E., and Szmidt, A. E. 1999. Properties of AFLP markers in inheritance and genetic diversity studies of Pinus sylvestris L. Heredity 82:252-260.

23. Li, X., Dorsch, M., Del Dot, T., Sly, L. I., Stackebrandt, E., and Hayward, A. C. 1993. Phylogeny of biovars of Pseudomonas solanacearum based on sequencing of 16S rRNA. ACIAR Proc. 45:93-95.

24. Louws, F. J., Rademaker, J. L. W., and de Bruijn, F. J. 1999. The three D's of PCR-based genomic analysis of phytobacteria: Diversity, detection, and disease diagnosis. Annu. Rev. Phytopathol. 37:81-125.

25. Pegg, K., and Moffett, M. 1971. Host range of the ginger strain of Pseudomonas solanacearum in Queensland. Aust. J. Exp. Agric. Anim. Husb. 11:696-698.

26. Poussier, S., Trigalet-Demery, D., Vandewalle, P., Goffinet, B., Luisetti, J., and Trigalet, A. 2000. Genetic diversity of Ralstonia solanacearum as assessed by PCR-RFLP of the hrp gene region, AFLP and 16s rRNA sequence analysis, and identification of an African subdivision. Microbiology 146:1679-1692.

27. Poussier, S., Vandewalle, P., and Luisetti, J. 1999. Genetic diversity of African and worldwide strains of Ralstonia solanacearum as determined by PCR-restriction fragment length polymorphism analysis of the hrp gene region. Appl. Environ. Microbiol. 65:2148-2194.

28. Priou, S., Gutarra, L., and Alsy, P. 1999. Highly sensitive detection of Ralstonia solanacearum in latently infected potato tubers by post-enrichment ELISA on nitrocellulose membrane. EPPO/OEEP Bull. 29:117125.

29. Quinon, V. L., Aragaki, M., and Ishii, M. 1964. Pathogenicity and serological relationship of three strains of Pseudomonas solanacearum in Hawaii. Phytopathology 54:1096-1099.

30. Seal, S., and Elphinstone, J. 1994. Advances in identification and detection of Pseudomonas solanacearum. Pages 35-57 in: Bacterial Wilt: The Disease and Its Causative Agent, Pseudomonas solanacearum. A. C. Hayward and G. L. Hartman, eds. CAB International, Wallingford, UK.

31. Seal, S. E., Jackson, L. A., Young, J. P. W., and Daniels, M. J. 1993. Differentiation of Pseudomonas solanacearum, Pseudomonas syzygii and the blood disease bacterium by partial $16 \mathrm{~S}$ rRNA sequencing: Construction of oligonucleotide primers for sensitive detection by polymerase chain reaction. J. Gen. Microbiol. 139:1587-1594.

32. Sneath, P. H. A., and Sokal, R. R. 1973. Numerical Taxonomy. Freeman, San Francisco.

33. Steiger, D. L., Nagai, C., Moore, P. H., Morden, C. W., Osgood, R. V., and Ming, R. 2002. AFLP analysis of genetic diversity within and among Coffea arabica cultivars. Theor. Appl. Genet. 105:209-215.

34. Taghavi, M., Hayward, C., Sly, L. I., and Fegan, M. 1996. Analysis of the phylogenetic relationships of strains of Burkholderia solanacearum, Pseudomonas syzygii, and the blood disease bacterium of banana based on 16S rRNA gene sequences. Int. J. Syst. Bacteriol. 46:10-15.

35. Vos, P., Hogers, R., Bleeker, M., Reijans, M., van de Lee, T., Hornes, M., Frijters, A., Pot, J., Peleman, J., Kuiper, M., and Zabeau, M. 1995. AFLP: A new technique for DNA finger printing. Nucleic Acids Res. 23:4407-4414. 